\title{
Study on Cytotoxicity and Virus Titration of Chitosan Nanoparticles Encapsulated Live PPR Virus Vaccine
}

\author{
J. Akalya* \\ Cattle Breeding and Fodder Development, Perambalur, Tamilnadu, India \\ *Corresponding author
}

\begin{tabular}{|c|c|}
\hline & A B S T R A C T \\
\hline $\begin{array}{l}\text { Ke y w o r d s } \\
\text { Chitosan, PPRV, } \\
\text { Vero cells, } \\
\text { Cytotoxicity, } \\
\text { Titration }\end{array}$ & \multirow{3}{*}{ 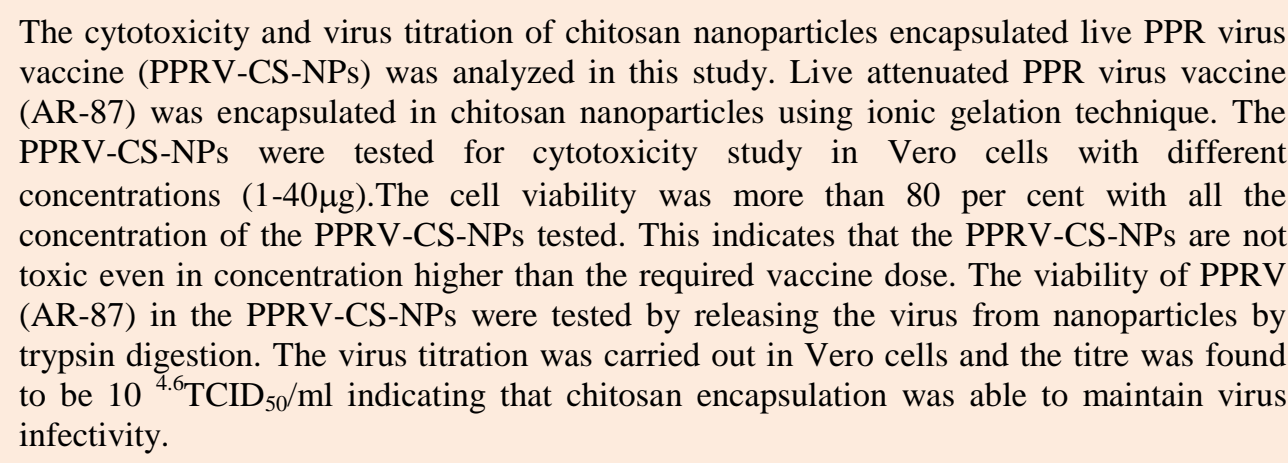 } \\
\hline Article Info & \\
\hline $\begin{array}{l}\text { Accepted: } \\
\text { 15 June } 2019 \\
\text { Available Online: } \\
\text { 10 July } 2019\end{array}$ & \\
\hline
\end{tabular}

\section{Introduction}

Peste des petits ruminants (PPR) or goat plague is a highly contagious viral disease of small ruminants such as sheep and goat (Dhar et al., 2002; Asim et al., 2009). Peste des petits ruminants virus is transmitted between animals such as sheep and goat and other small ruminants (Furley et al., 1987) through inhalation of aerosols and direct contact with ocular / nasal secretions, faeces, contaminated water and feed troughs (Saliki et al., 1993).

In India the first outbreak of PPR was reported by Shaila et al., (1989) and the disease has become endemic in India and causing severe economic losses to the small ruminant population of the country. The disease is controlled in endemic areas through administration of a live attenuated PPRV vaccine (Diallo, 2003). Three live attenuated vaccines currently available for use in India include: Sungri 96, Arasur 87 and Coimbatore 97 (Saravanan et al., 2010). The live attenuated PPR vaccines are thermolabile and require cold chain maintenance till administration.

In recent years attention has been directed towards the use of nanoparticles as delivery vehicles for vaccines. Nanoparticles are solid colloidal particles with diameters ranging from 1-1000 $\mathrm{nm}$. The vaccine antigen is either encapsulated within or decorated onto the 
surface of the nanoparticles. As a polyatomic, non- atomic, biodegradeable and biocompatible polymer, chitosan has attracted significant attention and can encapsulate a range of bioactive agents including proteins and peptides.

Chitosan nanoparticles can be prepared using various formulation methods to release active ingredients (such as proteins, peptides and DNA vaccines) in a sustained manner over a prolonged period. Among the encapsulation methods ionic cross linking method has received significant attention in recent years because the processes used are simple and mild for protein and viruses.

\section{Materials and Methods}

\section{Preparation of chitosan nanoparticles}

Vero cells adapted PPR vaccine virus (AR-87) maintained in the Department of Veterinary Microbiology, Madras Veterinary College, Chennai -7 was used in the study. Chiosan solution was prepared by dissolving chitosan $(1 \mathrm{mg} / \mathrm{ml}$ and $1.5 \mathrm{mg} / \mathrm{ml})$ with sonication in an aqueous solution of $4 \%$ acetic acid. Sodium Tripolyphosphate (TPP) was dissolved in triple distilled water at the concentration of $1 \mathrm{mg} / \mathrm{ml}$ and $1.5 \mathrm{mg} / \mathrm{ml}$. PPRV-CS-NPs was prepared using ionic cross linking method (Akalya et al., 2017).

\section{In vitro cytotoxicity of PPRV-CS-NPs}

Vero cells were transferred to 96 well plates at $100 \mu \mathrm{l}$ per well and cultured at $37^{\circ} \mathrm{C}$ in 5 per cent $\mathrm{CO}_{2}$ incubator. PPRV-CS-NPs were diluted to contain 1, 10, 20, 30 and $40 \mu \mathrm{g} / 200 \mu \mathrm{l}$ and added to vero cells. The 96 well plates were incubated in 5 per cent $\mathrm{CO}_{2}$ incubator at $37^{\circ} \mathrm{C}$ for $24-72 \mathrm{hr}$. Each concentration was added in duplicates/triplicates. Control well contained cells along with Dulbecco's Minimum
Essential Medium (DMEM) and Fetal Bovine Serum (FBS). MTT dye $(5 \mathrm{mg} / \mathrm{ml})$ was dissolved in triple distilled water. At the end of exposure period the nanoparticle suspension was removed and $200 \mu \mathrm{l}$ of fresh DMEM and 50 $\mu$ l of MTT dye were added to all wells. The plates were wrapped in alumininum foil and kept at $37^{\circ} \mathrm{C}$ for $4 \mathrm{hrs}$ in $\mathrm{CO}_{2}$ incubator. The medium containing dye was removed and the formazan crystals were dissolved by adding $200 \mu \mathrm{l}$ of DMSO. The absorbance was recorded at $570 \mathrm{~nm}$ and the per cent of cell viability was calculated with the following formula,

Cell viability $(\%)=\mathrm{At} / \mathrm{Ac} \mathrm{X} 100$

Where, At - Absorbance of test

Ac - Absorbance of control

\section{Determination of viral titre in the PPRV- CS-NPs}

One hundred micrograms of dried PPRV-CSNPs were added in to $10 \mathrm{ml}$ of PBS buffer (pH 7.2). Subsequently $2 \mathrm{ml}$ of trypsin was added to the above solution and then digested for $72 \mathrm{hr}$ at $4^{\circ} \mathrm{C}$ with a concentration of trypsin solution at $0.25 \%$ and centrifuged for $5 \mathrm{~min}$ at $1200 \mathrm{~g}$. The obtained supernatent was diluted with sterile saline by a serial of 10 fold dilution and $10^{-1}$ and $10^{-8}$ were inoculated into the vero cells and incubated at $37^{\circ} \mathrm{C}$ in 5 per cent $\mathrm{CO}_{2}$ incubator. Each dilution was tested in five replicates along with controls. The plates were incubated at $37^{\circ} \mathrm{C}$ in 5 per cent $\mathrm{CO}_{2}$ incubator and were examined for the development of CPE. Fifty per cent end point was calculated as per the method of Reed and Muench (1938).

\section{Results and Discussion}

Cytotoxicity study was performed to assess the cell viability after exposure to the PPRVCS-NPs. Vero cells were exposed to different 
concentrations of PPRV-CS-NPs from $1 \mu \mathrm{g}$ to $40 \mu \mathrm{g}$ and the cell viability was found to be more than 80 per cent in the concentration tested (Table 1). Though for vaccination of the animal less than $10 \mu \mathrm{g}$ of PPRV-CS-NPs would be needed the nanoparticles were not toxic even at $40 \mu \mathrm{g}$ concentration which indicated that the biocompatibility and the safety of the nanoparticles. The obtained results were in agreement with chitosan loaded with ciprofloxacin which was performed in human fibroblasts and found that there was no difference between the cells cultured in the medium containing chitosan nanoparticles and the cells cultured in the control medium (Hui and Changyou Gao, 2008).

Table.1 In vitro cytotoxicity study of PPRV - CS - NPs by MTT Assay

\begin{tabular}{|l|c|c|c|}
\hline S.NO & $\begin{array}{c}\text { Concentration } \\
\text { of PPR V-CS- } \\
\text { NPs }\end{array}$ & $\begin{array}{c}\text { Absorbance } \\
\text { value }\end{array}$ & $\begin{array}{c}\text { (Absorbance value of test } \\
\text { /Absorbance value of control) } \\
\text { X 100 }\end{array}$ \\
\hline & Control $(0 \mu \mathrm{g})$ & 1.819 & $100 \%$ \\
\hline $\mathbf{1 .}$ & $1 \mu \mathrm{g}$ & 1.697 & $93.2 \%$ \\
\hline $\mathbf{2 .}$ & $10 \mu \mathrm{g}$ & 1.527 & $83.9 \%$ \\
\hline $\mathbf{3 .}$ & $20 \mu \mathrm{g}$ & 1.5125 & $83.1 \%$ \\
\hline $\mathbf{4 .}$ & $30 \mu \mathrm{g}$ & 1.468 & $80.7 \%$ \\
\hline $\mathbf{5 .}$ & $40 \mu \mathrm{g}$ & 1.463 & $80.4 \%$ \\
\hline $\mathbf{6 .}$ & $50 \mu \mathrm{g}$ & 1.385 & $76.1 \%$ \\
\hline
\end{tabular}

In the present study the infectivity titre of the PPRV-CS-NPs were found to be $10^{4.6}$ $\mathrm{TCID}_{50} / \mathrm{ml}$ which is one log lesser than vaccine virus used for the preparation. The decrease in virus infectivity titre may be due to the prolonged trypsin digestion carried out for the release of virus from the PPRV-CSNPs. The findings of this study indicate that chitosan encapsulation by ionic gelation technique is able to maintain the virus infectivity and thus chitosan nanoparticles can act as delivery vehicle for live attenuated PPR vaccine.

\section{References}

Akalya, J., 2017. Preparation and Evaluation of Chitosan Encapsulated Live Peste des petits ruminants (PPR) Virus Vaccine. Indian Vet. J., 94(10): 27-29.

Asim, M., A. Rashid, A.H. Chaudhary and M.S. Noor, 2009. Production of homologous live attenuated cell culture vaccine for control of Peste des petits ruminants in small ruminant. Pakistan Vet. J. 29(2): 7274.

Dhar, P., B.P. Sreenivasa, T. Barrett, M. Corteyn, R.P. Singh and S.K. Bandyopadhyay, 2002. Recent epidemiology of peste des petits ruminants virus (PPRV). Vet. Microbiol. 88: 153-159.

Diallo, A., 2003. Control of peste des petits ruminants: Classical and new generation vaccines. Dev. Biol. Basel. 114: 113-119.

Furley, W., P.Taylor and T.U. Obi, 1987. An outbreak of peste des petits ruminants in a zoological collection. Vet. Rec. 121: 443-447.

Hui, L and C. Gao, 2008. Preparation and properties of ionically cross- linked chitosan nanoparticles. Polym. Adv. 
Technol. 20: 613-619.

K.Nachimuthu, A. Thangavelu, G. Dhinakarraj, R. Hegde and R.K. Singh, 2010. Comparative efficacy of peste des petits ruminants (PPR) vaccines. Biologicals. 38: 479- 485.

Reed, L.J and H. Muench, 1938. A simple method for estimating 50 per cent end points. Am. J. Hyg. 27: 493-497.

Saliki, J.T., G. Libeau, J.A. House, C.A. Mebus and J. Dubovi, 1993. A monoclonal antibody based blocking
ELISA for specific detection and titration of peste des petits ruminants antibody in caprine and ovine sera. $J$. Clin. Microbiol. 31: 1076-1082.

Saravanan, P., A. Sen, V. Balamurugan, K.K. Rajak, V. Bhanuprakash, K.S. Palaniswami, Shaila, M.S., V. Purushothaman, D. Bhavasar, K. Venugopal and R.A. Venkatesan, 1989. Peste des petits ruminants of sheep in India. Vet. Rec. 125: 602.

\section{How to cite this article:}

Akalya, J. 2019. Study on Cytotoxicity and Virus Titration of Chitosan Nanoparticles Encapsulated Live PPR Virus Vaccine. Int.J.Curr.Microbiol.App.Sci. 8(07): 2030-2033. doi: https://doi.org/10.20546/ijcmas.2019.807.243 